\title{
Temporal Trends in the Prevalence of Metabolic Syndrome among Middle-aged and Elderly adults from 2011 to 2015 in China: The China Health and Retirement Longitudinal Study (CHARLS)
}

Bo Liu

Beijing Xiaotangshan Hospital

\section{Guanqun Chen}

Capital Medical University https://orcid.org/0000-0002-8133-834X

Ruijie Zhao

Peking Union Medical College Hospital

Dan Huang

Beijing Xiaotangshan Hospital

Lixin Tao ( $\square$ taolixin@ccmu.edu.cn )

Capital Medical University, Beijing, China https://orcid.org/0000-0002-2135-046X

\section{Research article}

Keywords: Metabolic syndrome, Prevalence, Trends, Epidemiology, China

Posted Date: November 19th, 2020

DOI: https://doi.org/10.21203/rs.3.rs-109017/v1

License: (9) (i) This work is licensed under a Creative Commons Attribution 4.0 International License. Read Full License 


\section{Abstract}

Background: Metabolic syndrome (MetS) is a major risk factor for cardiovascular diseases. The objective of the study was to evaluate the updated prevalence of MetS and provide a comprehensive illustration of the possible temporal changes in MetS prevalence in China from 2011 to 2015.

Methods: The data for this study are from the 2011 and 2015 waves of the China Health and Retirement Longitudinal Study (CHARLS). CHARLS is a nationally representative survey targeting populations aged 45 and above from 28 provinces in mainland China. A total of 11847 and 13013 participants were eligible for data analysis at the two time points.

Results: The estimated prevalence of MetS in 2015 was $20.41 \%$ (95\% Cl: 19.02\%-21.8\%) by the ATP III criteria, 34.77\% (95\% Cl: 33.12\%-36.42\%) by the International Diabetes Federation (IDF) criteria, 39.68\% (95\% Cl: 37.88\%-41.47\%) by the revised ATP III criteria, and 25.55\% (95\% Cl: $24.19 \%-26.91 \%)$ by the Chinese Diabetes Society (CDS) criteria. The prevalence was higher among women and elderly adults and in urban and northern populations. Furthermore, the trends in the prevalence decreased significantly between 2011 and 2015 by the ATP III, revised ATP III and CDS criteria. However, trends increased significantly from 2011 to 2015 by the IDF criteria.

Conclusions: In China, elderly women living in northern urban areas should receive more attention. Notably, temporal changes in the prevalence of MetS varied somewhat according to different criteria.

\section{Background}

Metabolic syndrome (MetS) is a constellation of metabolic disturbances, including abdominal obesity, hypertension, dyslipidemia, and elevated plasma glucose [1, 2]. Studies have confirmed that the syndrome is associated with an increased risk of cardiovascular disease and other diseases [3-6]. In light of the substantial burden of cardiovascular disease in China [7], changes in the prevalence of MetS over time play an important reference and guidance role in decisions and implementation of public health measures regarding the control of cardiovascular disease.

Several nationally representative studies have provided evidence for the prevalence of MetS in the Chinese population. According to data from the International Collaborative Study of Cardiovascular Disease in ASIA (InterASIA), a cross-sectional study enrolled 15540 Chinese adults aged 35-74 years in 2000, and the prevalence of MetS was 13.7\% [8]. The China Health and Nutrition Survey (CHNS) conducted in 2009, which was a cross sectional study including a total of 7488 Chinese adults (age $\geq 18$ years), declared that the overall age-standardized prevalence of MetS was 21.3\% [9]. The 2010 China Noncommunicable Disease Surveillance (CNCDS) included 98658 Chinese adults (aged $\geq 18$ years) in 2010 and reported that the prevalence of MetS was 33.9\% [10]. Moreover, the China National Stroke Prevention Project (CSPP) survey in 2014-2015 estimated that the prevalence of MetS was 18.4\% based on data from 109551 participants [11]. The results of these national studies showed a high prevalence of MetS, which has become an important public health problem in China. However, it may be inappropriate to directly compare the results of these studies to reflect the possible temporal changes in MetS prevalence due to cross-sectional design, different sampling methods, inconsistent measurement of indicators, age range of participants and the definitions of MetS adopted.

Here, we used data from the China Health and Retirement Longitudinal Study (CHARLS) survey to describe the latest prevalence of MetS based on four different diagnostic criteria and then provide a comprehensive illustration of the possible temporal changes in MetS prevalence in China from 2011 to 2015.

\section{Methods}

\section{Study design and population}


Data for this study were obtained from the two waves of the CHARLS survey conducted by the National School of Development at Peking University in 2011 and 2015. Briefly, CHARLS is a nationally representative survey targeting populations aged 45 and above from 450 villages or communities in 150 counties or districts in 28 provinces of mainland China that provides a wide range of demographic, socioeconomic status and health condition variables. CHARLS participants were followed every 2 years using a face-to-face computer-assisted personal interview (CAPI). The baseline wave for the study was conducted between June 2011 and March 2012 and involved 17708 respondents with a response rate of $80.5 \%$. The research team collected blood samples from 11847 individuals. The second wave of the study was conducted in 2015 and involved 20284 respondents with a response rate of $87 \%$. A total of 13013 respondents provided venous blood. The details of the sampling design of this survey were previously described in an earlier publication [12].

The medical ethics committee approved the CHARLS study, and all interviewees were required to sign informed consent. Ethics approval for the data collection in CHARLS was obtained from the Biomedical Ethics Review Committee of Peking University (IRB00001052-11015). Ethics approval for the use of CHARLS data was obtained from the University of Newcastle Human Research Ethics Committee (H-2015-0290).

\section{Data collection}

At each county or district unit, trained staff collected data according to a standard protocol in respondents' homes and local health stations or the local office of the China Center for Disease Prevention and Control (CDC). Anthropometric measurements were performed by the interviewers who carried equipment into respondents' households. Systolic and diastolic blood pressure was measured three times in the left arm with an automated electronic device (OMRON Model HEM7112, Omron Company), with a 45 second interval between each measurement. The mean of the three measurements was used for analysis. Waist circumference (WC) was measured in a standing position the level of the umbilicus using a soft tape measure. The participants were instructed to not smoke, eat, drink, chew gum or brush their teeth when measuring.

After completing the questionnaires and measurements, $8 \mathrm{ml}$ fasting blood specimens were collected by trained nurses at township hospitals or the local office of the CDC. All blood samples were shipped back to Beijing at $-20^{\circ} \mathrm{C}$ and stored at $-70^{\circ} \mathrm{C}$ at the China CDC for analysis. Triglyceride (TG) and high-density lipoprotein cholesterol (HDL-C) levels were examined using an enzymatic colorimetric test. Blood glucose levels were assessed using the glucose oxidase method.

\section{Quality control}

Quality control measures were implemented during the fieldwork based on CAPI. Data verification was carried out by CHARLS headquarters. In addition, the first two visits of all interviewers were recorded to verify that the procedures executed were correct. If the recording could not be carried out due to technical problems or other reasons, staff from CHARLS headquarters would call these households for a phone check.

\section{Definition and diagnostic criteria}

MetS was defined according to four different definitions, including National Cholesterol Education Program (NCEP) Expert Panel on Detection, Evaluation, and Treatment of High Blood Cholesterol in Adults criteria (ATP III criteria) [13], criteria from the International Diabetes Federation (IDF criteria) [14], modified ATP III criteria for Asian populations [15], and Chinese Diabetes Society (CDS) criteria [16]. The details are shown in Table 1. 
Table 1

diagnosis criteria of metabolic syndrome used in the current study

\begin{tabular}{|c|c|c|c|c|}
\hline & $\begin{array}{l}\text { ATP III } \\
\text { criteria }\end{array}$ & IDF criteria & Modified ATP III criteria & CDS criteria \\
\hline $\begin{array}{l}\text { To be } \\
\text { identified as } \\
\text { MetS }\end{array}$ & $\begin{array}{l}\text { Any three or } \\
\text { more of the } \\
\text { following } \\
\text { five } \\
\text { components }\end{array}$ & $\begin{array}{l}\text { Central obesity plus } \\
\text { any two other factors }\end{array}$ & $\begin{array}{l}\text { Any three or more of the following } \\
\text { five components }\end{array}$ & $\begin{array}{l}\text { Any three or more of } \\
\text { the following five } \\
\text { components }\end{array}$ \\
\hline \multicolumn{5}{|c|}{$\begin{array}{l}\text { Central obesity } \\
\text { (waist } \\
\text { circumference) }\end{array}$} \\
\hline Men & $\otimes 102 \mathrm{~cm}$ & $\begin{array}{l}\geqq 90 \mathrm{~cm} \text { for Chinese } \\
\text { men }\end{array}$ & $\geqq 90 \mathrm{~cm}$ for Asian men & $\geqq 90 \mathrm{~cm}$ \\
\hline Women & $\triangle 88 \mathrm{~cm}$ & $\begin{array}{l}\geqq 80 \mathrm{~cm} \text { for Chinese } \\
\text { women }\end{array}$ & $\geqq 80 \mathrm{~cm}$ for Asian women & $\geqq 85 \mathrm{~cm}$ \\
\hline Elevated TG & $\begin{array}{l}\geqq 1.70 \\
\mathrm{mmol} / \mathrm{L}(150 \\
\mathrm{mg} / \mathrm{dL})\end{array}$ & $\begin{array}{l}\geqq 1.70 \mathrm{mmol} / \mathrm{L} \text { ( } 150 \\
\mathrm{mg} / \mathrm{dL} \text { ) } \mathrm{mg} / \mathrm{dL} \text { or } \\
\text { specific treatment for } \\
\text { this lipid abnormality }\end{array}$ & $\begin{array}{l}\geqq 1.70 \mathrm{mmol} / \mathrm{L}(150 \mathrm{mg} / \mathrm{dL}) \text { or } \\
\text { drug treatment for elevated TG }\end{array}$ & $\begin{array}{l}\geqq 1.70 \mathrm{mmol} / \mathrm{L}(150 \\
\mathrm{mg} / \mathrm{dL})\end{array}$ \\
\hline \multicolumn{5}{|l|}{ Low HDL-C } \\
\hline Men & $\begin{array}{l}\bigotimes 1.04 \\
\mathrm{mmol} / \mathrm{L}(40 \\
\mathrm{mg} / \mathrm{dL})\end{array}$ & $\begin{array}{l}\nabla 1.04 \mathrm{mmol} / \mathrm{L}(40 \\
\mathrm{mg} / \mathrm{dL} \text { ) in males or } \\
\text { specific treatment for } \\
\text { this lipid abnormality }\end{array}$ & $\begin{array}{l}\text { 1.04 mmol/L }(40 \mathrm{mg} / \mathrm{dL}) \text { in men } \\
\text { or drug treatment for reduced } \\
\text { HDL-C }\end{array}$ & $\begin{array}{l}\bigotimes 1.04 \mathrm{mmol} / \mathrm{L}(40 \\
\mathrm{mg} / \mathrm{dL})\end{array}$ \\
\hline Women & $\begin{array}{l}\bigotimes 1.29 \\
\mathrm{mmol} / \mathrm{L}(50 \\
\mathrm{mg} / \mathrm{dL})\end{array}$ & $\begin{array}{l}\otimes 1.29 \mathrm{mmol} / \mathrm{L}(50 \\
\mathrm{mg} / \mathrm{dL} \text { ) in females or } \\
\text { specific treatment for } \\
\text { this lipid abnormality }\end{array}$ & $\begin{array}{l}\otimes 1.29 \mathrm{mmol} / \mathrm{L}(50 \mathrm{mg} / \mathrm{dL}) \text { in } \\
\text { women or drug treatment for } \\
\text { reduced } \mathrm{HDL}-\mathrm{C}\end{array}$ & $\begin{array}{l}\bigotimes 1.04 \mathrm{mmol} / \mathrm{L}(40 \\
\mathrm{mg} / \mathrm{dL})\end{array}$ \\
\hline Elevated BP & $\begin{array}{l}\geqq 130 / 85 \\
\mathrm{~mm} \mathrm{Hg}\end{array}$ & $\begin{array}{l}\mathrm{SBP} \geqq 130 \text { or } \mathrm{DBP} \geqq 85 \\
\mathrm{~mm} \mathrm{Hg} \text {, or treatment } \\
\text { of previously } \\
\text { diagnosed } \\
\text { hypertension }\end{array}$ & $\begin{array}{l}\geqq 130 \mathrm{~mm} \mathrm{Hg} \mathrm{SBP} \text { or } \geqq 85 \mathrm{~mm} \mathrm{Hg} \\
\text { DBP or on antihypertensive drug } \\
\text { treatment in a patient with a } \\
\text { history of hypertension }\end{array}$ & $\begin{array}{l}\text { SBP } \geqq 130 \text { or DBP } \\
\geqq 85 \mathrm{~mm} \mathrm{Hg} \text {, } \\
\text { previously diagnosed } \\
\text { hypertension }\end{array}$ \\
\hline Elevated FPG & $\begin{array}{l}\geqq 6.1 \\
\mathrm{mmol} / \mathrm{L}(110 \\
\mathrm{mg} / \mathrm{dL})\end{array}$ & $\begin{array}{l}\geqq 5.6 \mathrm{mmol} / \mathrm{L}(100 \\
\mathrm{mg} / \mathrm{dL}) \text {, or previously } \\
\text { diagnosed type } 2 \\
\text { diabetes }\end{array}$ & $\begin{array}{l}\geqq 5.6 \mathrm{mmol} / \mathrm{L}(100 \mathrm{mg} / \mathrm{dL}) \text { or } \\
\text { drug treatment for elevated } \\
\text { glucose }\end{array}$ & $\begin{array}{l}\geqq 6.1 \mathrm{mmol} / \mathrm{L}, 2 \mathrm{~h} \\
\text { plasma glucose } \geqq 7.8 \\
\mathrm{mmol} / \mathrm{L} \text {, or previously } \\
\text { diagnosed diabetes }\end{array}$ \\
\hline
\end{tabular}

\section{Statistical analysis}

Initially, we calculated the prevalence of MetS for the overall population and different subgroups by diagnostic criteria, sex, location (rural or urban areas), marital status, six age groups (45-50, 51-55, 56-60, 61-65, 66-70 and 71 years old), six regions (Southwest, South-Central, East, Northwest, North, and Northeast China), and components (central obesity, elevated TG, reduced HDL-C, elevated fasting plasma glucose and high blood pressure) in 2011 and 2015, respectively. A sample weight for the blood data was used, calculated from a logistic regression. Further, the prevalence was compared between 2011 and 2015 to reflect temporal trends. 
The Chi-square test was used for statistically testing categorical variables such as sex, location and marital status. The $P$ trend was displayed in the variables of age group and region. Logistic regression was performed to compare the prevalence of MetS in 2011 and 2015, adjusting for location and age level.

All analyses were completed in SAS statistical software Version 9.2 (SAS Institute Inc., Cary, North Carolina, USA), where all statistical significance was recorded at the 0.05 level and $P$ values were two-sided.

\section{Results}

\section{Characteristics of the study sample in 2011 and 2015}

A total of 11847 and 13013 subjects were ultimately included in 2011 and 2015, respectively. There was no significant difference in the distribution of sex and marital status. However, significant differences weret found for the distribution of age group, location and region. The frequency distributions of elderly subjects in urban areas and in the east in 2015 were significantly higher than those in 2011 . Table 2 shows the details of the sample demographics. 
Table 2

Demographic characteristics between two waves in 2011 and 2015

\begin{tabular}{|c|c|c|c|}
\hline & Baseline wave in 2011(11847) & Third wave in 2015(13 013) & $P$ value \\
\hline Female, n (\%) & 6336(53.52\%) & 7019(53.95\%) & 0.4989 \\
\hline Age group, n (\%) & & & $<0.0001$ \\
\hline $45-50$ & 2472(20.87\%) & $2143(16.47 \%)$ & \\
\hline $51-55$ & 1914(16.16\%) & 2092(16.08\%) & \\
\hline $56-60$ & 2418(20.41\%) & 2071(15.91\%) & \\
\hline $61-65$ & $1886(15.92 \%)$ & $2357(18.11 \%)$ & \\
\hline $66-70$ & 1288(10.87\%) & $1741(13.38 \%)$ & \\
\hline$\geq 71$ & $1868(15.77 \%)$ & $2609(20.05 \%)$ & \\
\hline Marital Status, n (\%) & & & 0.909 \\
\hline Married $^{a}$ & $9787(82.62 \%)$ & 10744(82.56\%) & \\
\hline Abnormal Status ${ }^{b}$ & 2059(17.38\%) & $2269(17.44 \%)$ & \\
\hline Location, n (\%) & & & 0.0128 \\
\hline Rural & 7529(63.56\%) & $8007(62.03 \%)$ & \\
\hline Urban & $4317(36.44 \%)$ & 4902(37.97\%) & \\
\hline Region, n (\%) & & & $<0.0001$ \\
\hline North-east & $847(7.15 \%)$ & $938(7.27 \%)$ & \\
\hline North & $1675(14.14 \%)$ & $1676(12.98 \%)$ & \\
\hline North-west & $955(8.06 \%)$ & $1022(7.92 \%)$ & \\
\hline East & 3634(30.68\%) & 4359(33.76\%) & \\
\hline South-central & $2661(22.46 \%)$ & $2840(21.99 \%)$ & \\
\hline South-west & 2074(17.51\%) & 2077(16.08\%) & \\
\hline
\end{tabular}

\section{Prevalence of MetS in 2011 and 2015}

The top half of Table 3 displays the total-, sex-, marital status- and location-specific prevalence of MetS based on different definitions among Chinese middle-aged and elderly adults in 2011. Overall, the prevalence of MetS was $21.18 \%(95 \% \mathrm{Cl}$ : 19.48\%-22.88\%), 29.57\% (95\% Cl: 27.52\%-31.61\%), 41.44\% (95\% Cl: 39.24\%-43.65\%) and 26.66\% (95\% Cl: 25.09\%-28.22\%) based on definitions of ATP III, IDF, modified ATP III and CDS criteria, respectively. The prevalence in women was significantly higher than that in men, and the prevalence in the urban population was significantly higher than that in the rural population regardless of the definitions used. There was no difference in prevalence between marital status except that the prevalence in married individuals was significantly higher than that in abnormal status using CDS criteria. Notably, the prevalence increased with age (Fig. 1). The top half of Additional file 1: Table S1 provides specific data. In addition, the prevalence was 
remarkably higher in the north population than in the south population regardless of the definitions used (Fig. 2, Panels a, b, c, and d). For exact data, see the top half of Additional file 1: Table S2.

The total-, sex-, marital status- and location-specific prevalence of MetS based on different definitions among Chinese middleaged and elderly adults in 2015 were summarized in the bottom half of Table 3. Overall, the prevalence of MetS was $20.41 \%$ (95\% Cl: 19.02\%-21.8\%), 34.77\% (95\% Cl: 33.12\%-36.42\%), 39.68\% (95\% Cl: 37.88\%-41.47\%) and 25.55\% (95\% Cl:

24.19\%-26.91\%) based on definitions of ATP III, IDF, revised ATP III and CDS criteria, respectively. The prevalence in women was significantly higher than that in men, except the prevalence was similar using CDS criteria. In addition, the prevalence in urban areas was significantly higher than that in rural areas regardless of the criteria applied. Interestingly, there was no difference in prevalence between marital status. Similar to the description in 2011, the prevalence increased with age except for the prevalence based on IDF criteria (Figure 1, the numeric data in the bottom half of Additional file 1: Table S1). The prevalence was higher in the northern population than in the southern population regardless of the definitions used (Fig. 2, Panels e, $f, g$, and h). Data are shown in the bottom half of Additional file 1: Table S2. 
Table 3

Total, sex-, marital status- and location-specific prevalence of metabolic syndrome based on different definitions in 2011 and 2015

\begin{tabular}{|c|c|c|c|c|c|}
\hline & $\mathbf{n}$ & ATP III criteria & IDF criteria & Modified ATP III criteria & CDS criteria \\
\hline \multicolumn{6}{|l|}{2011} \\
\hline Total & 11846 & 21.18(19.48-22.88) & 29.57(27.52-31.61) & 41.44(39.24-43.65) & $26.66(25.09-28.22)$ \\
\hline \multicolumn{6}{|l|}{ Gender } \\
\hline Male & 5502 & $14.12(12.55-15.7)$ & $18.4(16.59-20.22)$ & $32.54(30.4-34.68)$ & $24.62(22.68-26.57)$ \\
\hline Female & 6336 & 27.72(25.45-29.98) & $39.9(37.11-42.68)$ & 49.69(46.24-53.14) & $28.56(26.65-30.48)$ \\
\hline$P$ value & & $<0.0001$ & $<0.0001$ & $<0.0001$ & 0.0007 \\
\hline \multicolumn{6}{|l|}{ Marital Status } \\
\hline Married & 9787 & 20.89(19.54-22.24) & $30.04(28.16-31.92)$ & 42.06(39.76-44.36) & 27.45(25.79-29.1) \\
\hline Abnormal status & 2059 & 22.52(19.51-25.53) & 27.61(24.37-30.85) & $38.87(34.87-42.86)$ & 23.32(20.29-26.35) \\
\hline$P$ value & & 0.3197 & 0.2049 & 0.1684 & 0.0203 \\
\hline \multicolumn{6}{|l|}{ Location } \\
\hline Rural & 7529 & 19.26(17.95-20.57) & $26.14(24.45-27.83)$ & 35.64(33.8-37.48) & 22.06(20.62-23.5) \\
\hline Urban & 4317 & 23.22(20.47-25.97) & 33.2(30.16-36.24) & 47.61(44.38-50.84) & $31.54(28.56-34.52)$ \\
\hline$P$ value & & 0.0099 & $<0.0001$ & $<0.0001$ & $<0.0001$ \\
\hline \multicolumn{6}{|l|}{2015} \\
\hline Total & 11013 & 20.41(19.02-21.8) & $34.77(33.12-36.42)$ & 39.68(37.88-41.47) & $25.55(24.19-26.91)$ \\
\hline \multicolumn{6}{|l|}{ Gender } \\
\hline Male & 5991 & $12.12(10.6-13.64)$ & 25.57(23.83-27.32) & $31.96(29.91-34.01)$ & $25.94(23.95-27.93)$ \\
\hline Female & 7019 & $28.01(26.46-29.56)$ & 43.2(41.14-45.25) & $46.74(44.72-48.76)$ & 25.2(23.78-26.62) \\
\hline$P$ value & & $<0.0001$ & $<0.0001$ & $<0.0001$ & 0.5052 \\
\hline \multicolumn{6}{|l|}{ Marital Status } \\
\hline Marriaged ${ }^{a}$ & 10744 & $20.1(18.76-21.44)$ & $34.6(33.02-36.18)$ & $39.42(37.73-41.11)$ & $25.81(24.44-27.18)$ \\
\hline $\begin{array}{l}\text { Abnormal } \\
\text { status }^{b}\end{array}$ & 2269 & 21.97(19.79-24.15) & 35.63(33.19-38.07) & $40.96(38.41-43.51)$ & 24.3(22.09-26.52) \\
\hline$P$ value & & 0.1407 & 0.4807 & 0.3175 & 0.2583 \\
\hline \multicolumn{6}{|l|}{ Location } \\
\hline Rural & 8008 & $17.3(16.15-18.44)$ & $28.39(26.98-29.81)$ & $32.84(31.39-34.29)$ & $20.42(19.17-21.68)$ \\
\hline Urban & 4904 & $23.59(21.23-25.96)$ & $41.27(38.6-43.94)$ & $46.65(43.59-49.7)$ & $30.78(28.55-33.01)$ \\
\hline$P$ value & & $<0.0001$ & $<0.0001$ & $<0.0001$ & $<0.0001$ \\
\hline
\end{tabular}




\section{Prevalence of MetS components in 2011 and 2015}

The prevalence of MetS components in the total study population in 2011 and 2015 is shown in Figure 3. Although the prevalence rate of components varies widely by the different diagnostic criteria, the components are very common in China. For example, the prevalence of elevated blood pressure in 2011 was 38.93\% (95\% Cl: 37.08\%-40.77\%), 50.58\% (95\% Cl: 48.74\%-52.43\%) and 50.58\% (95\% Cl: 48.74\%-52.43\%) based on definitions of ATP III, IDF/revised ATP III and CDS criteria, respectively. See Additional file 1: Table S3 for details.

\section{Changes in the prevalence of MetS over time from 2011 to 2015}

Table 4 shows the temporal changes in the total-, sex-, location-, marital status-, age- and region-specific prevalence of MetS based on four different definitions over time from 2011 to 2015. Overall, the changes in the prevalence depend on the selected definition. For example, the trends in the total-, rural-, married-, and south-central- specific prevalence decreased significantly between 2011 and 2015 based on definitions of ATP III, revised ATP III and CDS criteria. The male- specific prevalence decreased significantly between 2011 and 2015 based on definitions of ATP III and revised ATP III criteria. In contrast, the trends prevalence in the total group and many subgroups increased significantly between 2011 and 2015 based on definitions of IDF criteria. See Table 4 for a detailed list of results. 
Table 4

Changes in the total-, sex-, location-, marital status-, age- and region-specific prevalence of metabolic syndrome based on different definitions over time from 2011 to 2015

\begin{tabular}{|c|c|c|c|c|c|c|c|c|}
\hline \multirow[t]{2}{*}{$\begin{array}{l}2015 \text { vs } \\
2011\end{array}$} & \multirow{2}{*}{$\begin{array}{l}\begin{array}{l}\text { ATP III } \\
\text { criteria }\end{array} \\
\text { OR }(95 \% \mathrm{Cl})\end{array}$} & \multicolumn{3}{|c|}{ IDF criteria } & \multicolumn{2}{|c|}{ Modified ATP III criteria } & \multicolumn{2}{|l|}{ CDS criteria } \\
\hline & & $P$ value & OR $(95 \% \mathrm{Cl})$ & $P$ value & OR (95\% Cl) & $P$ value & OR $(95 \% \mathrm{Cl})$ & $\begin{array}{l}P \\
\text { value }\end{array}$ \\
\hline Total & $\begin{array}{l}0.904 \\
(0.851,0.961)\end{array}$ & 0.0011 & $\begin{array}{l}1.152 \\
(1.092,1.215)\end{array}$ & $<0.0001$ & $\begin{array}{l}0.892 \\
(0.848,0.938)\end{array}$ & $<0.0001$ & $\begin{array}{l}0.931 \\
(0.879,0.986)\end{array}$ & 0.0146 \\
\hline \multicolumn{9}{|l|}{ Gender } \\
\hline Male & $\begin{array}{l}0.767 \\
(0.687,0.856)\end{array}$ & $<0.0001$ & $\begin{array}{l}1.282 \\
(1.171,1.404)\end{array}$ & $<0.0001$ & $\begin{array}{l}0.895 \\
(0.826,0.969)\end{array}$ & 0.0064 & $\begin{array}{l}1.001 \\
(0.918,1.092)\end{array}$ & 0.9764 \\
\hline Female & $\begin{array}{l}0.964 \\
(0.894,1.039)\end{array}$ & 0.3364 & $\begin{array}{l}1.087 \\
(1.015,1.165)\end{array}$ & 0.0177 & $\begin{array}{l}0.878 \\
(0.82,0.94)\end{array}$ & 0.0002 & $\begin{array}{l}0.877 \\
(0.812,0.947)\end{array}$ & 0.0008 \\
\hline \multicolumn{9}{|l|}{ Location } \\
\hline Rural & $\begin{array}{l}0.879 \\
(0.811,0.953)\end{array}$ & 0.0017 & $\begin{array}{l}1.096 \\
(1.022,1.175)\end{array}$ & 0.0102 & $\begin{array}{l}0.88 \\
(0.824,0.94)\end{array}$ & 0.0001 & $\begin{array}{l}0.908 \\
(0.842,0.981)\end{array}$ & 0.014 \\
\hline Urban & $\begin{array}{l}0.92 \\
(0.838,1.011)\end{array}$ & 0.0831 & $\begin{array}{l}1.225 \\
(1.126,1.334)\end{array}$ & $<0.0001$ & $\begin{array}{l}0.889 \\
(0.819,0.965)\end{array}$ & 0.005 & $\begin{array}{l}0.939 \\
(0.859,1.026)\end{array}$ & 0.165 \\
\hline \multicolumn{9}{|l|}{$\begin{array}{l}\text { Marital } \\
\text { status }\end{array}$} \\
\hline Married $^{\mathrm{a}}$ & $\begin{array}{l}0.904 \\
(0.846,0.967)\end{array}$ & 0.0032 & $\begin{array}{l}1.126 \\
(1.062,1.195)\end{array}$ & $<0.0001$ & $\begin{array}{l}0.875 \\
(0.827,0.925)\end{array}$ & $<0.0001$ & $\begin{array}{l}0.927 \\
(0.87,0.987)\end{array}$ & 0.0181 \\
\hline $\begin{array}{l}\text { Abnormal } \\
\text { Status }^{b}\end{array}$ & $\begin{array}{l}0.903 \\
(0.781,1.043)\end{array}$ & 0.166 & $\begin{array}{l}1.281 \\
(1.127,1.456)\end{array}$ & 0.0002 & $\begin{array}{l}0.977 \\
(0.865,1.103)\end{array}$ & 0.704 & $\begin{array}{l}0.951 \\
(0.827,1.095)\end{array}$ & 0.4881 \\
\hline \multicolumn{9}{|l|}{$\begin{array}{l}\text { Age } \\
\text { group }\end{array}$} \\
\hline $45-50$ & $\begin{array}{l}0.887 \\
(0.762,1.032)\end{array}$ & 0.1218 & $\begin{array}{l}1.15 \\
(1.012,1.308)\end{array}$ & 0.0321 & $\begin{array}{l}0.897 \\
(0.794,1.013)\end{array}$ & 0.0794 & $\begin{array}{l}0.922 \\
(0.8,1.063)\end{array}$ & 0.2625 \\
\hline $51-55$ & $\begin{array}{l}0.901(0.775 \\
, 1.047)\end{array}$ & 0.1733 & $\begin{array}{l}1.201 \\
(1.051,1.372)\end{array}$ & 0.0072 & $\begin{array}{l}0.876 \\
(0.771,0.995)\end{array}$ & 0.041 & $\begin{array}{l}0.919 \\
(0.795,1.062)\end{array}$ & 0.2499 \\
\hline $56-60$ & $\begin{array}{l}0.864 \\
(0.749,0.996)\end{array}$ & 0.0438 & $\begin{array}{l}1.155 \\
(1.019,1.309)\end{array}$ & 0.0246 & $\begin{array}{l}0.886 \\
(0.786,0.999)\end{array}$ & 0.0488 & $\begin{array}{l}0.908 \\
(0.793,1.039)\end{array}$ & 0.1609 \\
\hline $61-65$ & $\begin{array}{l}1.001(0.867 \\
, 1.157)\end{array}$ & 0.984 & $\begin{array}{l}1.102 \\
(0.97,1.252)\end{array}$ & 0.1374 & $\begin{array}{l}0.859 \\
(0.76,0.97)\end{array}$ & 0.0147 & $\begin{array}{l}0.916 \\
(0.8,1.048)\end{array}$ & 0.2023 \\
\hline $66-70$ & $\begin{array}{l}0.798 \\
(0.673,0.946)\end{array}$ & 0.0092 & $\begin{array}{l}1.076 \\
(0.924,1.253)\end{array}$ & 0.3438 & $\begin{array}{l}0.868 \\
(0.75,1.004)\end{array}$ & 0.0572 & $\begin{array}{l}0.94 \\
(0.8,1.104)\end{array}$ & 0.448 \\
\hline$\geq 71$ & $\begin{array}{l}0.887 \\
(0.768,1.024)\end{array}$ & 0.102 & $\begin{array}{l}1.17 \\
(1.027,1.332)\end{array}$ & 0.0182 & $\begin{array}{l}0.891 \\
(0.789,1.006)\end{array}$ & 0.0627 & $\begin{array}{l}0.908 \\
(0.791,1.042)\end{array}$ & 0.1691 \\
\hline \multicolumn{9}{|l|}{ Region } \\
\hline $\begin{array}{l}\text { North- } \\
\text { East }\end{array}$ & $\begin{array}{l}0.988 \\
(0.798,1.223)\end{array}$ & 0.9092 & $\begin{array}{l}1.245 \\
(1.025,1.513)\end{array}$ & 0.0273 & $\begin{array}{l}0.89 \\
(0.738,1.073)\end{array}$ & 0.2218 & $\begin{array}{l}1.111 \\
(0.904,1.365)\end{array}$ & 0.3174 \\
\hline North & $\begin{array}{l}0.984 \\
(0.845,1.146)\end{array}$ & 0.8374 & $\begin{array}{l}1.339 \\
(1.165,1.539)\end{array}$ & $<0.0001$ & $\begin{array}{l}0.91 \\
(0.795,1.042)\end{array}$ & 0.1725 & $\begin{array}{l}0.98 \\
(0.847,1.133)\end{array}$ & 0.7861 \\
\hline $\begin{array}{l}\text { North- } \\
\text { West }\end{array}$ & $\begin{array}{l}0.817 \\
(0.652,1.023)\end{array}$ & 0.0782 & $\begin{array}{l}1.331 \\
(1.097,1.616)\end{array}$ & 0.0038 & $\begin{array}{l}0.977 \\
(0.815,1.172)\end{array}$ & 0.8016 & $\begin{array}{l}0.989 \\
(0.8,1.222)\end{array}$ & 0.9162 \\
\hline
\end{tabular}




\begin{tabular}{|c|c|c|c|c|c|c|c|c|}
\hline East & $\begin{array}{l}0.907 \\
(0.815,1.01)\end{array}$ & 0.0755 & $\begin{array}{l}1.135 \\
(1.033,1.247)\end{array}$ & 0.0082 & $\begin{array}{l}0.901 \\
(0.824,0.986)\end{array}$ & 0.0238 & $\begin{array}{l}0.914 \\
(0.826,1.012)\end{array}$ & 0.0836 \\
\hline $\begin{array}{l}\text { South- } \\
\text { Central }\end{array}$ & $\begin{array}{l}0.817 \\
(0.718,0.928)\end{array}$ & 0.002 & $\begin{array}{l}0.961 \\
(0.858,1.076)\end{array}$ & 0.4898 & $\begin{array}{l}0.793 \\
(0.712,0.884)\end{array}$ & $<0.0001$ & $\begin{array}{l}0.814 \\
(0.72,0.921)\end{array}$ & 0.001 \\
\hline $\begin{array}{l}\text { South- } \\
\text { West }\end{array}$ & $\begin{array}{l}0.935 \\
(0.79,1.106)\end{array}$ & 0.4314 & $\begin{array}{l}1.188 \\
(1.027,1.375)\end{array}$ & 0.0203 & $\begin{array}{l}0.945 \\
(0.827,1.079)\end{array}$ & 0.403 & $\begin{array}{l}0.964 \\
(0.825,1.128)\end{array}$ & 0.6496 \\
\hline
\end{tabular}

Note: OR, odds ratio; $\mathrm{Cl}$, confidence interval; ${ }^{a}$ married with spouse present; ${ }^{b}$ married but not living with spouse temporarily for reasons such as work, separated, divorced, widowed and never married.

\section{Changes in the prevalence of MetS components over time from 2011 to 2015}

Table 5 indicates the changes in the prevalence of central obesity, elevated triglyceride (TG), reduced HDL cholesterol (HDLC), high fasting glucose and high blood pressure between 2011 and 2015. The prevalence of central obesity and elevated triglycerides increased, and the prevalence of reduced HDL-C and high fasting glucose decreased regardless of the definitions used. However, the prevalence of high blood pressure increased based on definitions of the ATP III criteria, but did not change according to IDF, revised ATP III or CDS criteria.

Table 5

Changes in the prevalence of components of metabolic syndrome based on different definitions over time from 2011 to 2015

\begin{tabular}{|c|c|c|c|c|c|c|}
\hline \multirow[t]{3}{*}{2015 vs 2011} & \multirow{2}{*}{\multicolumn{2}{|c|}{ ATP III criteria }} & \multirow{2}{*}{\multicolumn{2}{|c|}{$\begin{array}{l}\text { IDF criteria } \\
\text { /Modified ATP III } \\
\text { criteria }\end{array}$}} & \multicolumn{2}{|l|}{ CDS criteria } \\
\hline & & & & & & \\
\hline & OR $(95 \% \mathrm{Cl})$ & $P$ value & OR (95\% Cl) & $P$ value & OR (95\% Cl) & $P$ value \\
\hline Central obesity & $1.394(1.313,1.48)$ & $<0.0001$ & $1.609(1.53,1.691)$ & $<0.0001$ & $1.556(1.479,1.638)$ & $<0.0001$ \\
\hline Elevated TG & $1.307(1.237,1.381)$ & $<0.0001$ & $1.208(1.147,1.274)$ & $<0.0001$ & $1.307(1.237,1.381)$ & $<0.0001$ \\
\hline Reduced HDL-C & $0.741(0.704,0.78)$ & $<0.0001$ & $0.759(0.722,0.799)$ & $<0.0001$ & $0.512(0.481,0.545)$ & $<0.0001$ \\
\hline $\begin{array}{l}\text { Elevated fasting } \\
\text { plasma glucose }\end{array}$ & $0.412(0.386,0.44)$ & $<0.0001$ & $0.372(0.353,0.392)$ & $<0.0001$ & $0.502(0.473,0.534)$ & $<0.0001$ \\
\hline $\begin{array}{l}\text { High blood } \\
\text { pressure }\end{array}$ & $1.162(1.105,1.223)$ & $<0.0001$ & $1.048(0.997,1.101)$ & 0.0675 & $1.048(0.997,1.101)$ & 0.0675 \\
\hline
\end{tabular}

\section{Discussion}

Our study based on the CHARLS survey provided an updated estimate of the national prevalence of MetS and its temporal changes among adults aged 45 years and older in China. The estimated prevalence of MetS among adults aged $\geq 45$ years in 
2015 in China was $20.41 \%$ (95\% Cl: $19.02 \%-21.8 \%$ ) by ATP III criteria. This prevalence was considerably higher when using IDF, revised ATP III and CDS criteria with 34.77\% (95\% Cl: 33.12\%-36.42\%), 39.68\% (95\% Cl: 37.88\%-41.47\%) and 25.55\% (95\% Cl: $24.19 \%-26.91 \%)$, respectively. The prevalence decreased significantly from 2011 to 2015 based on ATP III, revised ATP III and CDS criteria. However, the prevalence increased significantly from 2011 to 2015 according to the IDF criteria.

Currently, there are no uniform diagnostic criteria for MetS. Although definitions agree on the essential components including central obesity, high TG, low HDL-C, elevated blood pressure and fasting glucose, the criteria of each component varied somewhat except for the IDF and CDS criteria (Table 1). The five components are given the same weight in the ATP III, revised ATP III and CDS criteria, but the IDF criteria emphasizes that the presence of abdominal obesity was necessary for diagnosis. Additionally relatively strict criteria were used for definitions of central obesity in ATP III criteria, low HDL-C in CDS criteria, and elevated fasting glucose in IDF and revised ATP III criteria. In this study, we found that the prevalence of MetS in 2015 was lowest based on the ATP III criteria (20.41\%), followed by the CDS definition (25.55\%) and IDF criteria (34.77\%), and highest when defined with the revised ATP III definition (39.68\%). The difference in the prevalence was due to differences in the diagnostic criteria for MetS. Similarly, CSPP survey including 109551 participants aged $\geq 40$ years from 30 provinces in China in 2014-2015 estimated that the latest prevalence of MetS was $18.4 \%$ by the ATP III criteria, $26.9 \%$ following by the IDF criteria, and highest by the revised ATP III criteria with 34.0\% [11]. The discrepancy in the prevalence of MetS based on the same diagnostic criteria between these two studies is presumably due to differences in sampling methods, participant age range, and methods of data collection. In addition, subgroup analysis suggested that the prevalence of MetS in women, older age groups, urban areas and the north was higher than that in men, younger age groups, rural areas and the south according to the different diagnostic criteria. These findings are consistent with previous studies $[8,9,17]$. Menopause, unhealthy lifestyles, such as a sedentary lifestyle, decrease in physical activity, and an unhealthy diet may explain this difference in MetS prevalence.

With rapid urbanization and an aging population, many studies have found that the prevalence of MetS increased from 2000 to 2012 in China $[8,10,18]$. However, findings from the CSPP study compared with several previous nationally representative studies using the same definition (the ATP III criteria) revealed that the prevalence of MetS in 2014-2015 was higher than that in 2000-2001 but lower than the estimated prevalence in 2009-2010 [11]. Therefore, the decreasing trend in the prevalence of MetS from 2009 to 2015 in that study is consistent with our findings based on ATP III, revised ATP III and CDS criteria between 2011 and 2015. However, the only exception was that the prevalence of MetS increased significantly from 2011 to 2015 based on the IDF criteria. Changes in the prevalence of five components of MetS from 2011 to 2015 might be responsible for this contrasting report on the temporal trends in the prevalence of MetS between different diagnostic criteria. Our findings suggested that the prevalence of central obesity, elevated TG and blood pressure significantly increased from 2011 to 2015 and are consistent with previous studies [19-23]. This could explain the finding that there is an increasing trend in the prevalence of MetS between 2011 and 2015 based on definitions of IDF criteria that required abdominal obesity as an essential criterion. Moreover, our findings showed that the prevalence of reduced HDL-C and high fasting glucose decreased from 2011 to 2015 and were also supported by previous studies [21, 24]. A possible explanation is that prevention and control of noncommunicable diseases became a national health strategy and that Chinese people had easier access to clinical resources following healthcare reforms in 2013. This could be an explanation for the finding that the trends in the prevalence of MetS decreased significantly between 2011 and 2015 based on the ATP III, revised ATP III and CDS criteria.

Our study has several strengths. First, the CHARLS study is a nationally representative longitudinal survey of middle-aged and elderly individuals in China, which enabled us to estimate the prevalence of MetS. Second, strict quality control assured a high quality of data collection and reliability of the findings. Third, we comprehensively described the possible temporal changes in the prevalence of MetS based on four definitions by comparing results from the same study at different time points. This study also has several limitations. First, there was a nonresponse rate of $19.5 \%$ in 2011 and $12 \%$ in 2015 , which could potentially undermine the representativeness of the study samples. Second, the current follow-up time might not be long enough to reflect the changes in the prevalence of MetS. Third, this research was an ecological study, using the group as the unit of observation and analysis. We report the subgroup prevalence and performed multivariate logistic regression to control for possible confounding factors. 


\section{Conclusions}

Regardless of the definitions, MetS is common in the general adult population in mainland China, particularly among women and elderly adults and in urban areas and the north. Notably, temporal changes in the prevalence of MetS may be opposite according to different criteria.

\section{Abbreviations}

ATP III criteria: National Cholesterol Education Program (NCEP) Expert Panel on Detection, Evaluation, and Treatment of High Blood Cholesterol in Adults criteria; CAPI: computer-assisted personal interview; CDC: the China Center for Disease Prevention and Control; CDS: Chinese Diabetes Society; CDS: the Chinese Diabetes Society; CHARLS: the China Health and Retirement Longitudinal Study; CHNS: the China Health and Nutrition Survey; CNCDS: the 2010 China Noncommunicable Disease Surveillance; CSPP: the China National Stroke Prevention Project; HDL-C: high-density lipoprotein cholesterol; IDF criteria: the International Diabetes Federation; InterASIA: the International Collaborative Study of Cardiovascular Disease in ASIA; MetS: Metabolic syndrome; TG: Triglyceride; WC: waist circumference.

\section{Declarations}

\section{Ethics approval and consent to participate}

The study was approved by the Biomedical Ethics Review Committee of Peking University (IRB00001052-11015). Ethics approval for the use of CHARLS data was obtained from the University of Newcastle Human Research Ethics Committee $(\mathrm{H}-$ 2015-0290). And all the participants gave their written informed consent before any study procedures began.

\section{Consent for publication}

Not applicable.

\section{Availability of data and materials}

The datasets used and/or analysed during the current study are available from the corresponding author on reasonable request.

\section{Competing interests}

The authors declare that they have no competing interests.

\section{Funding}

This study were funded by National Natural Science Foundation of China $(81872708,82073668)$ and Beijing Municipal Key Laboratory of Clinical Epidemiology. These funds cover the costs to publish the manuscript.

\section{Authors' contributions}

$\mathrm{BL}$ analyzed the data. BL and GC interpreted the data and drafted this manuscript. RZ and DH revised this manuscript. LT conceived the idea and revised this manuscript. All authors read and approved the final manuscript. 


\section{Acknowledgements}

We thank the China Health and Retirement Longitudinal Study (CHARLS) team for providing data.

\section{References}

1. Eckel RH, Grundy SM, Zimmet PZ (2005) The metabolic syndrome. Lancet 365(9468): 1415-1428. https://doi.org/10.1016/S0140-6736(05)66378-7

2. Grundy SM, Cleeman JI, Daniels SR, Donato KA, Eckel RH, Franklin BA, Gordon DJ, Krauss RM, Savage PJ, Smith SC, Spertus JA, Costa F (2005) Diagnosis and Management of the Metabolic Syndrome. Circulation 112(17): 2735-2752. https://doi.org/10.1161/CIRCULATIONAHA.105.169404

3. Park S, Lee S, Kim Y, Lee Y, Kang MW, Han K, Han SS, Lee H, Lee JP, Joo KW, Lim CS, Kim YS, Kim DK (2019) Altered Risk for Cardiovascular Events With Changes in the Metabolic Syndrome Status: A Nationwide Population-Based Study of Approximately 10 Million Persons. Ann Intern Med 171(12): 875-884. https://doi.org/10.7326/M19-0563

4. Mottillo S, Filion KB, Genest J, Joseph L, Pilote L, Poirier P, Rinfret S, Schiffrin EL, Eisenberg MJ (2010) The metabolic syndrome and cardiovascular risk a systematic review and meta-analysis. J Am Coll Cardiol 56(14): 1113-1132. https://doi.org/10.1016/j.jacc.2010.05.034

5. Raffaitin C, Gin H, Empana JP, Helmer C, Berr C, Tzourio C, Portet F, Dartigues JF, Alperovitch A, Barberger-Gateau P (2008) Metabolic Syndrome and Risk for Incident Alzheimer's Disease or Vascular Dementia: The Three-City Study. Diabetes Care 32(1): 169-174. https://doi.org/10.2337/dc08-0272

6. Frisardi V, Solfrizzi V, Seripa D, Capurso C, Santamato A, Sancarlo D, Vendemiale G, Pilotto A, Panza F (2010) Metaboliccognitive syndrome: A cross-talk between metabolic syndrome and Alzheimer's disease. Ageing Res Rev 9(4): 399-417. https://doi.org/10.1016/j.arr.2010.04.007

7. Liu S, Li Y, Zeng X, Wang H, Yin P, Wang L, Liu Y, Liu J, Qi J, Ran S, Yang S, Zhou M (2019) Burden of Cardiovascular Diseases in China, 1990-2016. JAMA Cardiol 4(4): 342. https://doi.org/10.1001/jamacardio.2019.0295

8. Gu D, Reynolds K, Wu X, Chen J, Duan X, Reynolds RF, Whelton PK, He J, For TICG, InterASIA CG (2005) Prevalence of the metabolic syndrome and overweight among adults in China. Lancet 365(9468): 1398-1405. https://doi.org/10.1016/S0140-6736(05)66375-1

9. Xi B, He D, Hu Y, Zhou D (2013) Prevalence of metabolic syndrome and its influencing factors among the Chinese adults: The China Health and Nutrition Survey in 2009. Prev Med 57(6): 867-871. https://doi.org/10.1016/j.ypmed.2013.09.023

10. Lu J, Wang L, Li M, Xu Y, Jiang Y, Wang W, Li J, Mi S, Zhang M, Li Y, Wang T, Xu M, Zhao Z, Dai M, Lai S, Zhao W, Wang L, Bi Y, Ning G (2017) Metabolic Syndrome Among Adults in China: The 2010 China Noncommunicable Disease Surveillance. J Clin Endocrinol Metab 102(2): 507-515. https://doi.org/10.1210/jc.2016-2477

11. Li W, Song F, Wang X, Wang L, Wang D, Yin X, Cao S, Gong Y, Yue W, Yan F, Zhang H, Sheng Z, Wang Z, Lu Z (2018) Prevalence of metabolic syndrome among middle-aged and elderly adults in China: current status and temporal trends. Ann Med 50(4): 345-353. https://doi.org/10.1080/07853890.2018.1464202

12. Zhao Y, Hu Y, Smith JP, Strauss J, Yang G (2014) Cohort Profile: The China Health and Retirement Longitudinal Study (CHARLS). Int J Epidemiol 43(1): 61-68. https://doi.org/10.1093/ije/dys203

13. Expert Panel On Detection EATO, Expert Panel On Detection EATO (2001) Executive Summary of the Third Report of the National Cholesterol Education Program (NCEP) Expert Panel on Detection, Evaluation, and Treatment of High Blood Cholesterol in Adults (Adult Treatment Panel III). JAMA 285(19): 2486-2497. https://doi.org/10.1001/jama.285.19.2486

14. Alberti KG, Zimmet P, Shaw J (2006) Metabolic syndrome-a new world-wide definition. A Consensus Statement from the International Diabetes Federation. Diabet Med 23(5): 469-480. https://doi.org/10.1111/j.1464-5491.2006.01858.x

15. Alberti KG, Eckel RH, Grundy SM, Zimmet PZ, Cleeman JI, Donato KA, Fruchart JC, James WP, Loria CM, Smith SJ (2009) Harmonizing the metabolic syndrome: a joint interim statement of the International Diabetes Federation Task Force on

Page $14 / 21$ 
Epidemiology and Prevention; National Heart, Lung, and Blood Institute; American Heart Association; World Heart Federation; International Atherosclerosis Society; and International Association for the Study of Obesity. Circulation 120(16): 1640-1645. https://doi.org/10.1161/CIRCULATIONAHA.109.192644

16. Chinese guidelines on prevention and treatment of dyslipidemia in adults (revised in 2016). Zhonghua Xin Xue Guan Bing Za Zhi 44(10): 833-853.

17. Li R, Li W, Lun Z, Zhang H, Sun Z, Kanu JS, Qiu S, Cheng Y, Liu Y (2016) Prevalence of metabolic syndrome in mainland china: a meta-analysis of published studies. BMC Public Health 16(1): 210-296. https://doi.org/10.1186/s12889-0162870-y

18. He Y, Li Y, Bai G, Zhang J, Fang Y, Zhao L, Zhao W, Yang X, Ding G (2019) Prevalence of metabolic syndrome and individual metabolic abnormalities in China, 2002-2012. Asia Pac J Clin Nutr 28(3): 621-633.

https://doi.org/10.6133/apjcn.201909_28(3).0023

19. Mi Y, Zhang B, Wang H, Yan J, Han W, Zhao J, Liu D, Tian Q (2015) Prevalence and Secular Trends in Obesity Among Chinese Adults, 1991-2011. Am J Prev Med 49(5): 661-669. https://doi.org/10.1016/j.amepre.2015.05.005

20. Chen Y, Peng Q, Yang Y, Zheng S, Wang Y, Lu W (2019) The prevalence and increasing trends of overweight, general obesity, and abdominal obesity among Chinese adults: a repeated cross-sectional study. BMC Public Health 19(1): https://doi.org/10.1186/s12889-019-7633-0

21. Song PK, Man QQ, Li H, Pang SJ, Jia SS, Li YQ, He L, Zhao WH, Zhang J (2019) Trends in Lipids Level and Dyslipidemia among Chinese Adults, 2002-2015. Biomed Environ Sci 32(8): 559-570. https://doi.org/10.3967/bes2019.074

22. Guo J, Zhu Y, Chen Y, Hu Y, Tang X, Zhang B (2015) The dynamics of hypertension prevalence, awareness, treatment, control and associated factors in Chinese adults. J Hypertens 33(8): 1688-1696.

https://doi.org/10.1097/HJH.0000000000000594

23. Lu J, Lu Y, Wang X, Li X, Linderman GC, Wu C, Cheng X, Mu L, Zhang H, Liu J, Su M, Zhao H, Spatz ES, Spertus JA, Masoudi FA, Krumholz HM, Jiang L (2017) Prevalence, awareness, treatment, and control of hypertension in China: data from 1.7 million adults in a population-based screening study (China PEACE Million Persons Project). Lancet 390(10112): 2549-2558. https://doi.org/10.1016/s0140-6736(17)32478-9

24. Li Y, Teng D, Shi X, Qin G, Qin Y, Quan H, Shi B, Sun H, Ba J, Chen B, Du J, He L, Lai X, Li Y, Chi H, Liao E, Liu C, Liu L, Tang X, Tong N, Wang G, Zhang J, Wang Y, Xue Y, Yan L, Yang J, Yang L, Yao Y, Ye Z, Zhang Q, Zhang L, Zhu J, Zhu M, Ning G, Mu Y, Zhao J, Teng W, Shan Z (2020) Prevalence of diabetes recorded in mainland China using 2018 diagnostic criteria from the American Diabetes Association: national cross sectional study. BMJ. https://doi.org/10.1136/bmj.m997

\section{Figures}



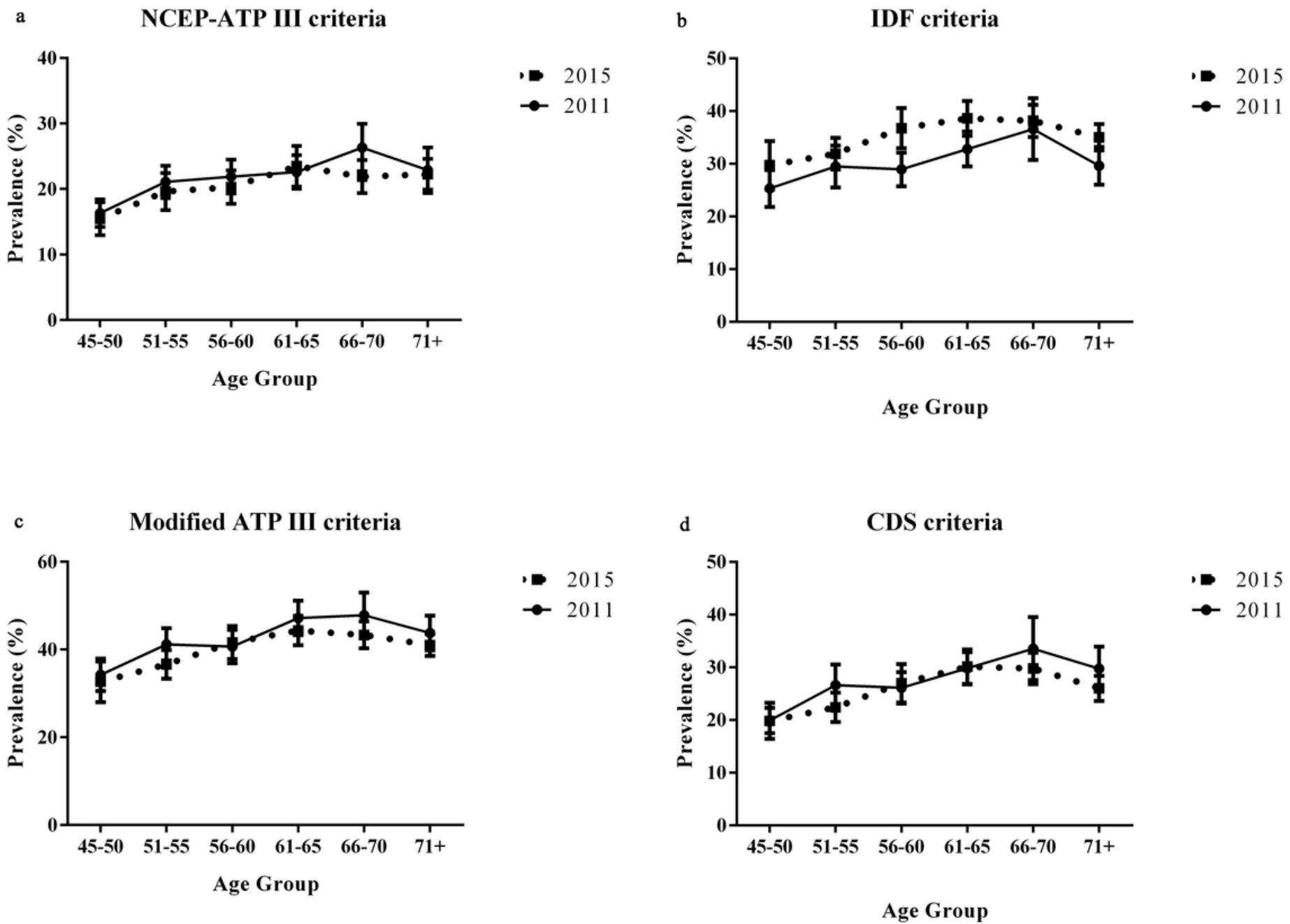

Figure 1

Age-specific prevalence of metabolic syndrome based on different definitions in 2011 and 2015. Figure a, b, c, and d shows the prevalence of metabolic syndrome between different age groups based on ATP III, IDF, revised ATP III and CDS criteria, respectively. Dotted line represents the baseline wave and a solid line represents the third wave. 

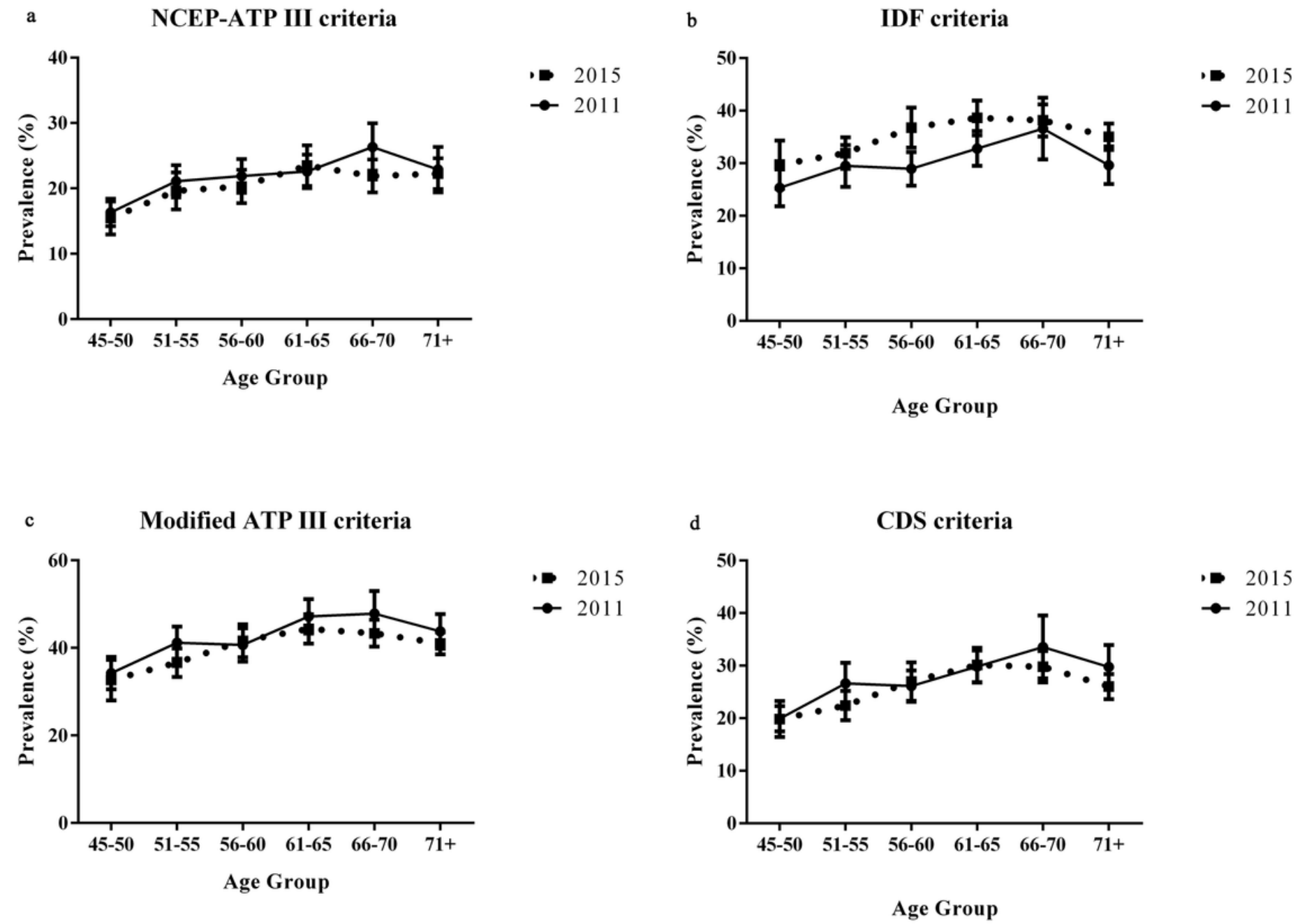

Figure 1

Age-specific prevalence of metabolic syndrome based on different definitions in 2011 and 2015. Figure a, b, c, and d shows the prevalence of metabolic syndrome between different age groups based on ATP III, IDF, revised ATP III and CDS criteria, respectively. Dotted line represents the baseline wave and a solid line represents the third wave. 

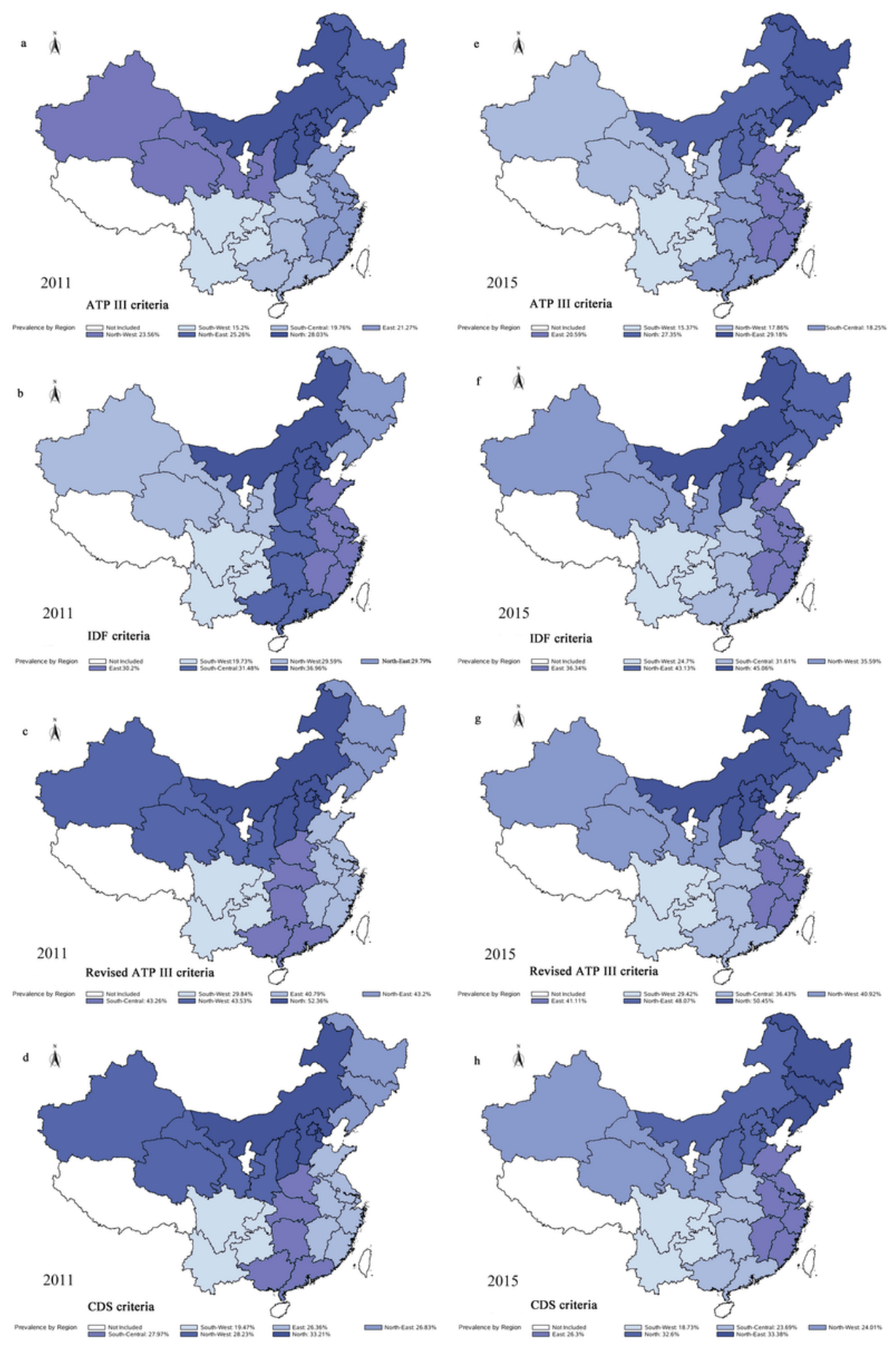

\section{Figure 2}

Region-specific prevalence of metabolic syndrome based on different definitions in 2011 and 2015. Figure a, b, c, and d indicate the prevalence of metabolic syndrome in different regions in 2011 based on ATP III, IDF, revised ATP III and CDS criteria, respectively. Figure e, $f, g$, and $h$ indicates the prevalence of metabolic syndrome in different regions in 2015 based on ATP III, IDF, revised ATP III and CDS criteria, respectively. Different colors represent different regions of China. Individuals living in Hainan, Ningxia, Taiwan, and Tibet were not included in the surveys. Note: The designations employed and the presentation of the material on this map do not imply the expression of any opinion whatsoever on the part of Research Square concerning the legal status of any country, territory, city or area or of its authorities, or concerning the delimitation of its frontiers or boundaries. This map has been provided by the authors. 

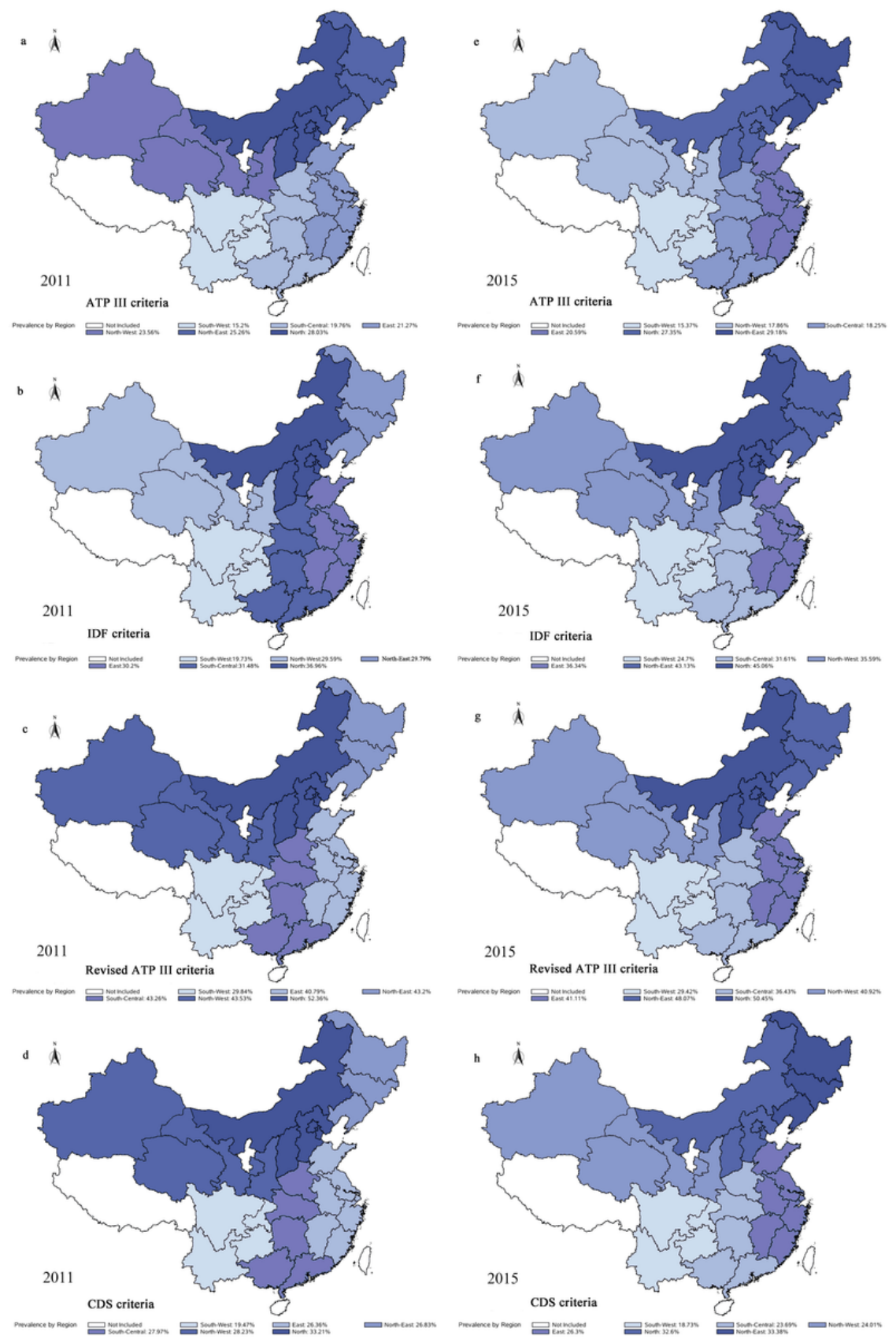

\section{Figure 2}

Region-specific prevalence of metabolic syndrome based on different definitions in 2011 and 2015. Figure a, b, c, and d indicate the prevalence of metabolic syndrome in different regions in 2011 based on ATP III, IDF, revised ATP III and CDS criteria, respectively. Figure e, $f, g$, and $h$ indicates the prevalence of metabolic syndrome in different regions in 2015 based on ATP III, IDF, revised ATP III and CDS criteria, respectively. Different colors represent different regions of China. Individuals living in Hainan, Ningxia, Taiwan, and Tibet were not included in the surveys. Note: The designations employed and the presentation of the material on this map do not imply the expression of any opinion whatsoever on the part of Research Square concerning the legal status of any country, territory, city or area or of its authorities, or concerning the delimitation of its frontiers or boundaries. This map has been provided by the authors. 
a

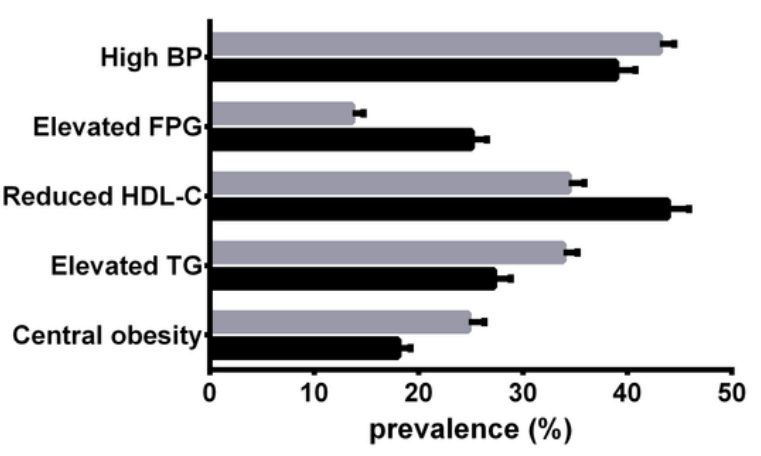

b

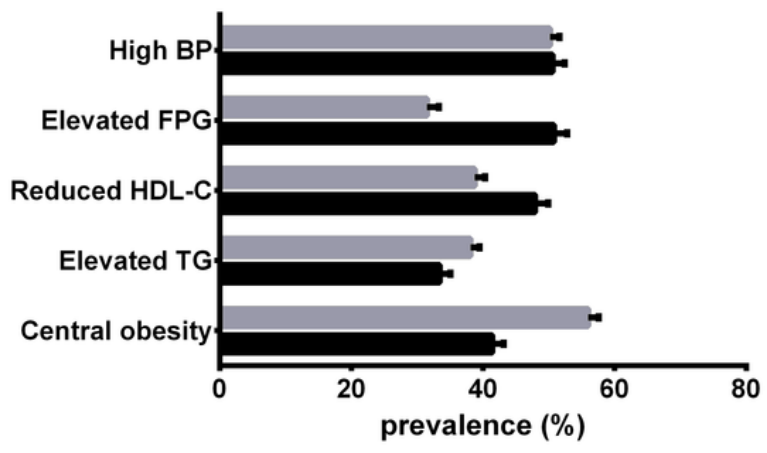

c

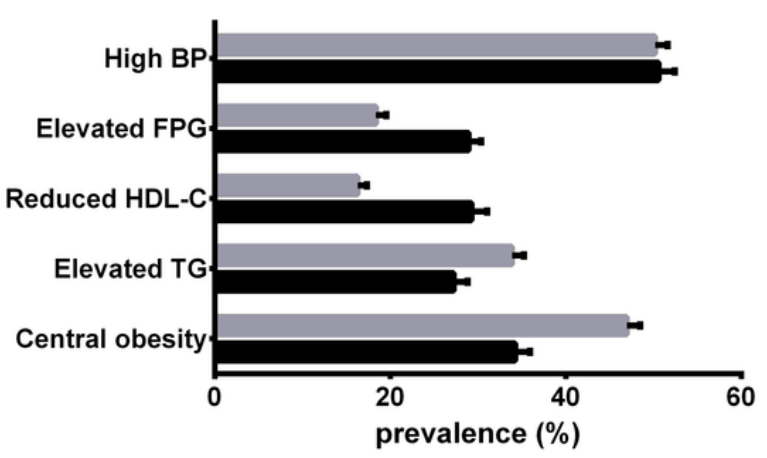

2011

2015
2011

2015
2011

2015

\section{Figure 3}

Prevalence of components of metabolic syndrome based on different definitions in 2011 and 2015. Figure a, b, and c shows prevalence of components of metabolic syndrome in 2011 and 2015 based on ATP III, IDF/revised ATP III and CDS criteria, respectively. Dark bar graph represents the baseline wave and gray bar graph represents the third wave. 
a

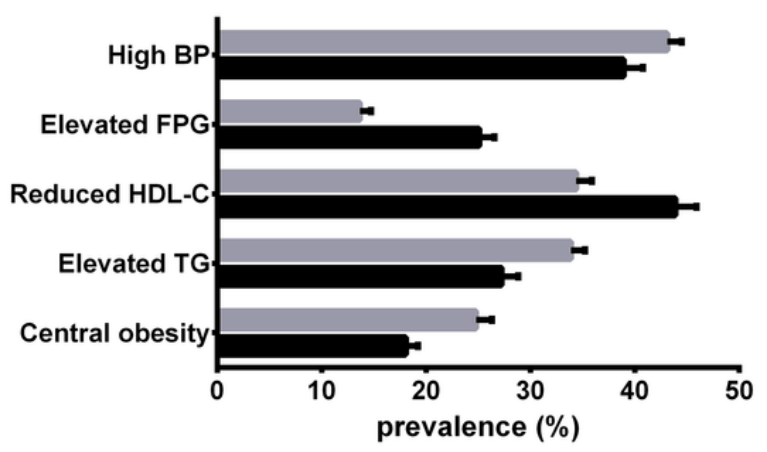

b

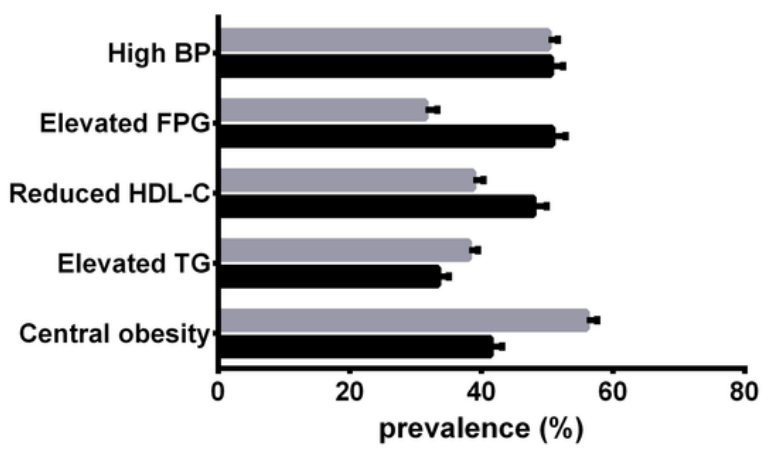

c

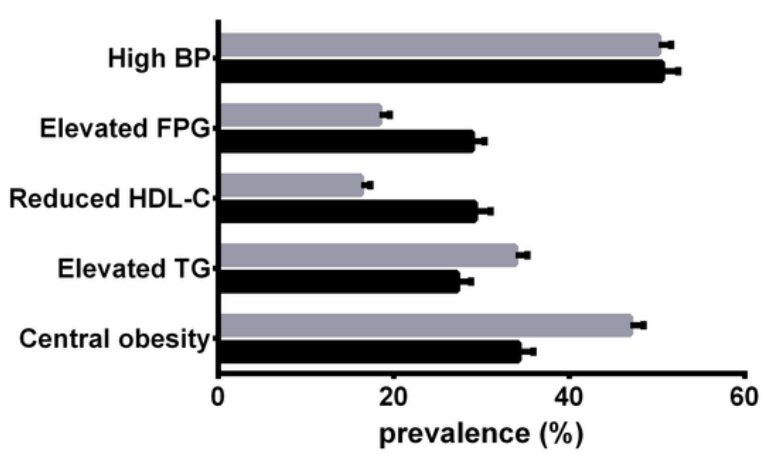

2011

2015
2011

2015
2011

2015

\section{Figure 3}

Prevalence of components of metabolic syndrome based on different definitions in 2011 and 2015. Figure a, b, and c shows prevalence of components of metabolic syndrome in 2011 and 2015 based on ATP III, IDF/revised ATP III and CDS criteria, respectively. Dark bar graph represents the baseline wave and gray bar graph represents the third wave.

\section{Supplementary Files}

This is a list of supplementary files associated with this preprint. Click to download.

- Additionalfile1.docx

- Additionalfile1.docx 